\title{
VAK GYERMEKEK NYELV- ÉS BESZÉDFEJLÖDÉSÉNEK SAJÁTOS VONÁSAI ÉS HÁTTERE
}

\author{
PAJOR EMESE ${ }^{1}$ - BEKE ANNA MÁRIA ${ }^{2}$ - CSÉPE VALÉRIA ${ }^{3}$ \\ ${ }^{1}$ Eötvös Loránd Tudományegyetem Bárczi Gusztáv Gyógypedagógiai Kar \\ ${ }^{2}$ Semmelweis Egyetem I. Sz. Szülészeti és Nógyógyászati Klinika \\ ${ }^{3}$ MTA TTK Agyi Képalkotó Központ Neurokognitív Fejlődés Kutatócsoport
}

E-mail: emese.pajor@gmail.com

Beérkezett: 2018. szeptember 27. - Elfogadva: 2019. február 8.

Célkitűzés: Áttekintố tanulmányunk célja egy kevéssé kutatott terület, a súlyos fokban látássérült (vak) gyermekek nyelv-és beszédfejlōdésének bemutatása.

Módszertan: A témában kevés publikáció jelent meg, leginkább esettanulmányok, aminek oka a populáció (nagyon) kis elemszáma és a vak gyermekek egymástól jelentôsen eltérố fejlödési üteme. A vizsgálatok és publikációk hiányát tovább fokozza, hogy a magyar nyelvi sajátosságok nehezen hasonlíthatók a kutatások zömét nyújtó angol nyelvú irodalom tényeihez. Tanulmányunkban a témában keletkezett kutatások eredményeit mutatjuk be.

Következtetések: A vak gyermekek nyelv-és beszédfejlödésében megfigyelhetố eltérések különösen a fogalmak és reprezentációk kialakulásában, illetve a kommunikáció területén jelentôsek, melyek iskoláskorra csökkennek. Látó gyermekekkel összehasonlítva, a vak csoport esetén az auditív információk jobb kódolása, illetve a fonémaalapú szóelôhívási stratégia lehet a nagyobb verbális munkamemória-kapacitás és a fonémafluenciafeladatokban mérhetô jobb teljesítmény hátterében. A verbális munkamemória és a jobb auditív percepciós elôny felnöttkorra is jellemzố. Ennek neurális háttere biztositott, mivel vizuális depriváció hatására sem inaktív egy agykérgi terület sem. A vak gyermekek nyelv-és beszédfejlödésében ezért megnö a környezet szerepe.

Kulcsszavak: vakság, nyelv-és beszédfejlódés, idegrendszeri plaszticitás 


\section{BEVEZETÉS}

Az emberi nyelv keletkezésének tudományos vizsgálata a 20. század második felétôl a különbözó empirikus kutatási eredményeken alapuló modellek leírását eredményezte (Corballis, 2002; Hauser, Chomsky és Fitch, 2002). Az elméletek azonban nem statikusak, mivel bizonyos kutatási eredmények értelmezése továbbra is vita tárgya (Pléh, 2009). A nyelv pszichológiai kutatásának köszönhetően hazánkban is az elemzések fókuszába került többek között a megértés és a produkció kapcsolata (például Pléh és Lukács, 2001), a nyelvelsajátítás vizsgálata (például Egyed, Király, Krekó, Kupán és Gergely, 2007) vagy a nyelv és a gondolkodás viszonya (például Németh, 2006). Ugyancsak az elmúlt 20-25 évben számottevô kutatás történt a specifikus nyelvfejlôdési zavar (például Marton, 2009; Lukács, Kas és Leonard, 2013) vagy az autizmus spektrumzavar nyelvi jellegzetességeinek (például Győri, 2013), az értelmi fogyatékos személyek nyelvelsajátításának vizsgálata (például Radványi és Pléh, 2002), illetve a jelnyelvek pszicholingvisztikájának leírása (például Szabó, 2007) terén. Az atipikus nyelvelsajátítás vizsgálatának legnagyobb nehézsége a kis vizsgálati minta, illetve több esetben a vizsgált csoport számára kialakított, illetve standardizált mérôeszközök hiánya. Míg például a jelnyelvi kutatásban, az utóbbi években nagyobb jelnyelvi korpuszok létrehozására került sor (Johnston és Schembri, 2013, id. Sáfár, 2014), addig a súlyos fokban látássérült (vak) ${ }^{1}$ gyermekek nyelv- és beszédfejlôdésérôl kevés vizsgálatot és publikációt (Csákvári, 2009) olvashatunk. Hazánkban sem átfogó értekezés, sem kutatás nem született a témában, azonban BA-, illetve MA-szintû szakdolgozat vizsgált egy-egy nyelvi szempontból (kis mintájú) vak, illetve gyengénlátó csoportot (Kocsis, 1999; Mildner, 2003; Garai, 2004; Mészáros, 2004; Szúcsné, 2008; Pál, 2012). A nemzetközi szakirodalomban is kevés a témával foglalkozó publikáció, különösen a friss kutatások hiánya feltûnố.

A nyelvi nativizmus hipotéziséból kiindulva, vakság esetén a nyelvre egy olyan kompenzatorikus mechanizmusként kell tekinteni, mely érintetlen marad vizuális inger hiányakor, és amire képes a fejlődés is támaszkodni. Az elméleti iskola mögé sorakozik fel többek között Mills (1987), vagy Perez-Pereira és Conti-Ramsden (1999). Ôk a nyelvelsajátítás alternatív (holisztikus - Gestalt) stratégiáját feltételezik, szemben a látó gyermekek analitikus stratégiájával (Brambring, 2007).

A környezeti faktorokkal nagymértékben számoló megközelítés szerint „a veleszületett vakság nyelvi késéssel is jár, mert a hiányos tapasztalatszerzés a kogníció és/vagy a szociális kompetencia esetén negatív hatást gyakorol a nyelvfejlôdésre is" (Csákvári, 2009, 6). Urwin (1978), Dunlea (1989), vagy Andersen, Dunlea és Kekelis (1984) munkái épülnek erre a modellre (Brambring, 2007).

Dabrowska (2004) úgy véli, hogy ha a nyelvre mint csak innátfaktorra tekintünk, akkor a vak gyermekek nyelvfejlôdése nem különbözik a látókétól, mivel ók is ugyanúgy hallják a nyelvet, mint látó társaik, és ugyanaz az univerzális grammatika vonatkozik rájuk. Így Chomsky feltételezése igazolódik, miszerint esetükben a gyorsabb nyelvelsajátítást az innátfaktor megléte eredményezi, illetve az, hogy a vak gyermekek a vizuális

Súlyos fokú látássérült, vak: a fogalmat a 2006 WHO (BNO-10) csoportosításának megfelelôen használjuk: vakság (vízus 0,05-0) (www.who.org). 
input hiánya miatt sokkal inkább támaszkodnak a hallásukra, ezért a nyelvre - mint információforrásra - vannak utalva.

Az empirikus adatok szerint azonban a vak gyermekek nyelvelsajátítása során a nyelvi hármasság (szemantika, szintaxis, morfológia) késést és zavart mutat (Dunlea, 1989; Pérez-Pereira és Conti-Ramsden, 1999; id. Csépe, 2005). A vizualitás hiánya 40\%-ban beszédkéséssel és 76\%-ban beszédproblémákkal jár. A látó gyermekeknél elsôsorban fonetikai és fonológiai problémák tapasztalhatók, míg a vak gyermekeknél lexikaiszemantikai és morfoszintaktikai hibák fordulnak elô nagyobb számban. A súlyos fokban látássérült kisgyermekeknél a fonológiai emlékezeti terjedelem, vagy az auditív figyelem kisebb eltérésekor már elmaradás észlelhetô a beszédfejlődésben (Dabrowska, 2004).

\section{A VAK GYERMEKEK NYELV- ÉS BESZÉDFEJLÖDÉSE}

A vak csecsemô gagyogásában a látó csecsemôhöz viszonyítva nem tapasztalható kvalitatív eltérés. A látó csecsemôk, kisgyermekek a vizuális megerôsítés miatt a labiális hangok ejtésében jobbak a nem labiálisokhoz viszonyítva. Vak csecsemôk, kisgyermekek esetében nem találni ilyen szignifikanciát, inkább fordított összefüggés érvényesül. Egyes megfigyelések szerint az elsố hangok idôi megjelenésében és az ejtési helyességben náluk nincs preferencia. Az intonációs és kiejtési problémák ugyanakkor huzamosabb ideig fennmaradnak (Barry, 2002).

Korai vizsgálatok szerint - összefoglalja Dunlea (1989) - tehát a látó csecsemók gyorsabban és kevesebb hibával tanulják meg a látható artikulációs mozgással képezhetố hangokat, mint például a b, w. Míg a vak gyermekek akusztikus hasonlóság alapján tévesztik a hangokat $(\mathrm{m}, \mathrm{n})$, addig a látó gyermekeknél a vizualitás is befolyásolja a hangcserét $(b, m)$. Vak csecsemóknél idôben elhúzódhat az expresszív gagyogás és a holofrázisok idôszaka, késhet a kétszavas periódus és a távirati stílus.

Bár a vak gyermekek nyelvfejlődése hasonló a látó gyermekekéhez (Brambring, 2007), mégis megfigyelhetô néhány jellegzetes eltérés. Egyértelmú késés mutatkozik a szótagprodukcióban (production of syllables) vagy az elsố jelentésteli szavak megjelenésében, azonban kevéssé tapasztalható eltérés a 10 vagy az 50 szavas szótár idôi kialakulásában (Bigelow, 2005). Vak gyermekeknél átlagosan 50 szavas szókincs után jelennek meg a két-, illetve háromszavas megnyilvánulások (Bigelow, 1986).

A vak gyermekek elsố szavai ugyanazok, mint a látó gyermekeké, még a „néz” szó is megjelenik. A szavak jelentéstartalma azonban korlátozott, gyakran nem a kontextusnak megfelelően használják azokat. Késôbb és kisebb számban jelennek meg, és kevésbé használják megfelelően a funkciószavakat (és, vagy) (Dunlea, 1989).

A szókincsükre jellemzó, hogy sokkal kevesebb állatnevet használnak, valószínúleg a képeskönyv-nézegetés hiánya miatt, azonban gyakrabban neveznek meg mindennapi tárgyakat, például bútorokat (Bigelow, 2005). Jellemzô továbbá, hogy kevesebb a túláltalánosítás (több az aluláltalánosítás), illetve hiányoznak, de mindenképpen késôbb jelennek meg a fantáziaszavak.

Dunlea és Andersen (1992) szerint, míg a látó gyermekeknél a temporális szelf és maga az idố fogalmának kialakulása a beszédhez kötött oly módon, hogy a beszéd állványozza az idố megértését, vagyis a „beszéd után következik az idô”, addig a vak gyer- 
mekeknél ez éppen fordítva van, az idô megértése vonja magával a beszédet, vagyis náluk „az idô után következik a beszéd”.

A látó gyermekekhez viszonyítva nagyobb számban és hosszabb ideig figyelhetô meg náluk az echolália és a névmáscsere. A szelf-fejlôdéssel összefüggésben nagy késés figyelhetô meg az E/1 igealakok, illetve a személyes névmás (én) használatában, helyettük sokáig a saját nevüket használják a vak gyermekek, sokkal hosszabb ideig, mint ahogy a látó gyermekeknél megfigyelhetô. Angolszász nyelvek esetén a fônévi nemek megjelenése nagyon sokat késik (Barry, 2002). ${ }^{2}$ Mind a segédigék, mind a téri prepozíciók használatában késést lehet tapasztalni (Brambring, 2006). Brambring (2007) a személyes és birtokos névmások használatának egyévnyi késését írja le. A vak gyermekek beszéde több imperatív igealakot tartalmaz, mint látó társaiké. Ennek oka, hogy a vak gyermekek 1,4-1,10 éves kora között az anyák az interakciók során leggyakrabban az imperatív igealakot használják. Szintén nagy számban használnak kijelentô mondatot, továbbá kevés eldöntendô kérdést tesznek fel (Dunlea, 1989). Kisszámú továbbá az „itt és most” aktivitásról való közlés, így a vak gyermek egy korlátozott nyelvi mintát kap. Jellemzô továbbá, hogy a szülôk inkább címkéznek (label focused speech), vagy a gyermekkel a tárgyakat neveztetik meg, mintsem a tevékenységet, illetve nem az explorációt, az aktivitást írják le. Mindez szintén erôsíti az aluláltalánosításokat (Dabrowska, 2004).

Pring (1992, id. Csépe, 2005) leírja, hogy egyes vak gyermekek a tárgyak megnevezésénél a taktilis rendszer számára megjelenó perceptuális hasonlóság mentén tévednek (például: virág-fogkefe tévesztése, mivel mindkettônek van szára és feje). A vak gyermekek több esetben a taktilitás helyett a tárgy nevét használják jelzóingerként annak felismerésekor. „Az adekvát perceptuális elemzés hiányában a tárgyak kategóriái eltérôen alakulnak, azaz a megosztott mentális aktivitás a rendelkezésre álló perceptuális tulajdonságok alacsonyabb szintú integrációjához vezet a jelentés és a kontextus feldolgozása során” (Pring 1992, id. Csépe, 2005, 159).

A vak gyermekek inkább saját akcióról beszélnek, mint másokéról, továbbá inkább múlt idôt használnak már a kétszavas periódusban. Ennek oka, hogy a felnôtt többet meséli a vele (gyermekkel) történt eseményeket. Megfigyelhetô továbbá, hogy gyakoribb a témacsere, és hosszabb idejû a mosoly. A „metakommunikatív” (figyelemfelhívó) jelek közül leginkább a másik megérintése a jellemzô.

A vak kisgyermekek beszéde több utánzást és ismétlést tartalmaz. A jellegzetes verbális szokások, és az ún. „futamok” - melyek hangsorok, intonációk, vagy akár mondatok is lehetnek - a látást kompenzálják, és egyfajta nyelvelsajátítási stratégiáról árulkodnak. Beszédükre jellemzó továbbá az angol, illetve a német nómenklatúra szerint a 'meaningless language' vagy verbalizmus, vagyis olyan szavak, kifejezések használata, melyek tapasztalati úton számukra megismerhetetlenek, érzékleti tartalommal nem rendelkeznek. Az irodalmias, a hétköznapi élettôl idegen, néha „funkciótlannak tûnô" beszédstílus az életkorral hangsúlyosabbá válhat.

Peters (1974, id. Hoff, 2005) egy magát „Didja”-nak (Did you) nevezó, 2 éves kisfiúról szóló esettanulmányában kiemeli, hogy a vak gyermekek számára a beszéd az egyet-

Az irodalom nem tartalmaz pontos idôket, így nem lehet tudni, hogy valójában mit jelentenek a menynyiségjelzôk (nagyon sokat, hosszabb ideig stb.). 
len ${ }^{\text {(sic!) }}$ interakciós lehetôség, ami a jelentés nélküli futamok elsajátítását és használatát eredményezheti. Az esettanulmányban szereplô kisfiú a múlt idejú segédigét és a you személyes névmást az E/1 személy kifejezésére használja, múlt idejú igealakot használ a jelen idô kifejezésére, azonban az ige alakja sem megfelelô. Néhány példa: Didja find it (I found it); Didja dump it out (I dumped it out); Didja burp (I burped).

Peters (1974) kiemeli, hogy a vak gyermek részéról kevés a kommunikációs kezdeményezés, ha van, akkor leginkább szelf-orientált a téma. A vizuális visszacsatolás hiánya miatt nehézséget okoz számára a társalgás fenntartása, így több kérdést tesz fel, hosszabb ideig beszél.

Landau és Gleitman (1985) szerint a vak és látó gyermekek között megfigyelhetô nyelvi különbségek 3 éves korra, de legkésôbb 5 éves korra rendezôdnek. Az 5 éves látó gyermekekhez hasonló eredményt érnek el az ugyanolyan életkorú vak gyermekek a nyelvi képességekkel kapcsolatos feladatokban, mint például az ejtésben cserélt hangok auditív megkülönböztetésében vagy az utánmondásban. A funkciószavak és az imperatív igealakok atipikus használata általában 10 éves korra rendezôdik (PérezPereira és Conti-Ramsden, 1999). 15 évesen azonos teljesítmény figyelhetô meg a fonémafluencia-feladatokban (Wakefield, Homewood és Taylor, 2006). Azonban a látás hiányában nehezített lehet a fogalmak, illetve a fogalmak közti összefüggések megértése, továbbá az általánosítás (Andersen, Dunlea és Kekelis, 1984).

\section{A VAKON SZÜLETETT SZEMÉLYEK KOGNITÍV KÉPESSÉGEI - A NYELVI ÉS VERBÁLIS MEMÓRIA FUNKCIÓI}

Kérdés az, hogy a vak gyermekeknél tapasztalható, több szempontból eltérô nyelvfejlôdés, annak ellenére, hogy az atipikus jegyei a vizsgálati eredmények szerint iskoláskorra eltûnnek, a késôbbi életkorban tetten érhetô-e egyfajta sajátos kognitív mintázatban? Kérdés továbbá az is, hogy vajon a vak személyek mindennapokban tapasztalható „jó” verbalitása mögött, a látókhoz viszonyítva, kimutathatóan jobb akusztikus észlelés, memóriafunkció, esetleg figyelmi múködés áll-e?

Bár egyre növekvô érdeklôdés figyelhetố meg a vak személyek észlelését, kognitív képességeit és különösen azok neurális alapjait vizsgáló kutatások eredményei iránt, sajnos a vak gyermekek körében végzett vizsgálatok száma elenyészô.

A vak gyermekek verbális tesztekkel mért kognitív képességeinek eredményeirôl összefoglalóan Prónay (2004) számol be. A Wechsler-tesztekkel végzett vizsgálatokból kiderül, hogy a 7-15 éves vak gyermekek a legalacsonyabb teljesítményt az általános ismeret, a számolási gondolkodás és az általános megértés szubtesztekben érték el, míg a legmagasabb pontokat a szókincs- és a számismétlés-feladatokra kapták. „A Szókincs és Számismétlés próbákban nyújtott teljesítmény, az akusztikus memóriát igénylô feladatok körébe is tartozva, felfogható úgy is, mint a látássérüléssel élő gyermekek speciális vagy klasszikus szóhasználattal élve kompenzatorikus készsége” (Prónay, 2004, 70).

A 7-15 éves, teljes magyar épértelmú vak populáció és az illesztett látó kontrollcsoport felmérésekor Pajor, Beke és Csépe (2016) vak és látó csoportok esetén csak a fonológiai fluenciafeladatnál talált szignifikáns eltérést. A vak és a látó csoportok 
mutatói szignifikánsan csak a fonémafluencia-feladatban tértek el. Az eredmények alapján Bliss, Kujala és Hamalainen (2004) vizsgálataihoz hasonlóan nem találtak a vakon született gyermekeknél a látókhoz viszonyítva jobb kognitív képességeket, beleértve a rövid távú (Hull és Mason, 1995) és hosszú távú memóriát (Röder és Rösler, 2003). A vak és a látó csoportok a munkamemória-feladatok közül csak a magyar álszóismétlési teszt esetén mutattak szignifikáns különbséget. Míg a kategóriák elôhívása azonos módon és mértékben történik a látó személyekhez viszonyítva, addig a fonémaalapú elôhívás mint szótalálási stratégia, jobb eredményhez vezet. A szavak keresése tehát számukra könnyebb fonémahangzás, mint kategória szerint (Pajor, Beke és Csépe, 2016).

Dekker (1993) kiemeli, hogy a vakon született gyermekek a verbális memóriára épülô feladatokban jobb eredményt érnek el, mint a látó, a késôbb megvakult és az aliglátó gyermekek. Álláspontja szerint a jobb memóriateljesítmények oka, hogy a vak személyek hatásosabban kódolják az auditív verbális információkat (Röder, Rösler és Neville, 2001). A munkamemória-feladatok esetén a vak csoportok elônyét írta le a látókkal szemben Röder és Neville (2003), illetve Hötting és Röder (2009), akik rámutattak arra, hogy az akusztikusan bemutatott szavakkal és számokkal végzett feladatok esetén a vakon született vizsgálati személyeknek „kifejezetten” (sic!) magasabb a munkamemória-kapacitásuk.

A vakon született felnôtt személyek látókéhoz viszonyított jobb kognitív és perceptuális képességérôl - beleértve a rövidtávú (Hull és Mason, 1995) és hosszútávú memóriát (Amedi, Raz, Pianka, Malach és Zohary, 2003; Röder és Rösler, 2003), a hallási diszkriminációt, a hangforrás-lokalizációt (Gougoux, Lepore, Lassonde, Voss, Zatorre és Belin, 2004) és a beszédpercepciót (Hugdahl és mtsai, 2004) - több kutatás is beszámol. Hötting, Rösler és Röder (2004) kiemelik, hogy a nonvizuális ingerek megkülönböztetésében jobb teljesítményt és kisebb reakcióidôt mutattak a vak személyek a látókhoz képest. Azonban az eredmények elemzése rámutat arra, hogy a perceptuális növekedés a nagyobb szenzoros szenzitivitás következménye (Collignon, Lassonde, Lepore, Bastien és Veraart, 2007). Ez a nagyobb szenzitivitás kifejezettebb azoknál a vak személyeknél, akiknél jobb auditív és taktilis diszkriminatív képességet mértek a hangmagasság (Gougoux és mtsai, 2004), a hangintenzitás vagy a téri irányok (Ashmead, Wall, Ebinger, Eaton, Snook-Hill és Yang, 1998) megkülönböztetésében. A vak személyek a látókhoz viszonyítva szintén szignifikánsan jobb eredményt érnek el az auditív monitorozási és a beszéddiszkriminációs feladatokban, továbbá a visszhangdetekcióra épülô mozgásos feladatokban (Hugdahl és mtsai, 2004). Ugyancsak jobb eredményt érnek el a látó kontrollhoz viszonyítva a csendes háttérben bemutatott, illetve zajba ágyazott hangok felismerésében (Rokem és Ahissar, 2009). Röder és Rösler (2003) vizsgálataikban vak és látó személyek auditív emlékezetét hasonlították össze különbözô kódolási stratégiák alapján. A vizsgálat során a felismerési szakaszban az elôzôleg hallott „régi” hangokat „új” hangokkal keverve kapták a személyek. Ezek az új, környezetbôl származó hangok fizikailag eltérôek, de azonos fogalomhoz tartoztak (például kutyaugatás két különbözô kutyától). A vizsgálat eredményei alapján elmondható, hogy míg a vakon született és a felnôttkorban megvakult személyek között nincs különbség az auditív memóriafeladatok eredményeiben, addig mindkét csoport magasabb pontszámokat ér el a látó személyekhez képest. 


\section{A VIZUÁLIS INGERTŐL MEGFOSZTOTT AGYKÉREG PLASZTICITÁSA}

Az utóbbi évtizedekben több kutatás keresi arra a választ, hogy vajon vizuális depriváció hatására megváltozik-e a kérgi és a kéreg alatti struktúra. Ha igen, akkor az befolyásolja-e a súlyos fokban látássérült kisgyermekek beszédfejlôdését?

A különbözô agyi képalkotó eljárásokkal végzett vizsgálatoknak köszönhetôen mára elfogadott tény, hogy a látás elvesztése nem jelenti a látókéreg inaktivitását: Braille-olvasáskor, taktilis vagy auditív ingerek felismerésekor a vak emberek vizuális kortexében - eltérô mértékû - aktivitás figyelhetô meg. Burton és munkatársai (2002), illetve Wanet-Defalque és munkatársai (1988) PET-vizsgálattal az elsôk között mutattak ki vakon született személyek okcipitális kérgében (striatális és prestriatális kérgi területek) aktivitást. Taktilis tárgyfelismerési és auditoros feladatok esetén az okcipitális kérgük aktív volt, bár vizuális inger nem érte azt. Eredményük szerint a pubertás fontos fejlôdési mérföldkövet jelent ennél az aktivitásnál.

Vak személyek esetén az auditoros kéreg expanziója bizonyított (Elbert, Sterr, Rockstroh, Pantev, Müller és Taub, 2002). Stevens és Weaver (2009) fMRI-tanulmányában vakon született, késóbbi életkorban megvakult és látó személyek kérgi aktivitását mérte tiszta hangok passzív hallgatásakor és frekvenciamodulált ingerek adásakor. Eredményeik szerint vak személyek esetén a tonotopikus organizáció az auditoros területek szuperior és középsố temporális lebenyeiben nem szignifikánsan változik. A vakon született személyek az ingert hatékonyabban képesek feldolgozni a kérgi analízis elsô szakaszában, vagyis az auditoros kérgi területekben létrejövố funkcionális válasz megváltozik a korai vizuális depriváció hatására. A vakon született személyek vizsgálatban mutatott jobb auditoros teljesítménye tehát a kérgi plaszticitás intramodális formájával magyarázható.

\section{Auditív percepció - Beszédfeldolgozás, nyelvi feladatok}

Vakon született személyeknél hanglokalizációs feladatok és beszédhang hallgatása és ismétlése esetén - EKP (eseményhez kötött agyi potenciál) komponensek alapján a poszterior kortikális (parietális és okcipitális) területek aktivitása figyelhetố meg (Kujala és mtsai, 1997).

Röder és munkatársai (2002) vizsgálataikban kimutatták, hogy vak személyeknél a bal oldali területekkel - felsố temporális sulcus és a temporális lebeny középsô gyrusa (Price, 1998) - homológ jobb oldali területek is aktívak a fonémafeldolgozás során. Mindezt a vizuális területek olyan aktivitása kíséri, amely a látó embereknél nem figyelhetô meg. A vak személyek azonos teljesítménye a nyelvi feladatokban, és a látókénál jobb teljesítménye a beszédhangok és a különbözô akusztikus ingerek percepciójában arra utal, hogy a kompenzáció a rendszer alsóbb szintjein érvényesül igazán (id. Csépe, 2005). Az fMRI-adatok is igazolták, hogy vak embereknél a vizuális input hiányában nem alakul ki az egyes területek rivalizációja, vagyis a nyelvi reprezentáció mindkét oldalon nagyobb területet foglal el.

Az okcipitális kéreg aktivitása figyelhetô meg vak személyeknél auditív nyelvi feladatok (például igeképzés) (Amedi, Jacobson, Hendler, Malach és Zohary, 2002; Amedi 
és mtsai, 2003), szemantikai döntéshelyzet és beszédfeldolgozás (Röder és mtsai, 2001) során. A vizsgálatot Amedi és munkatársai (2002) transzkraniális ingerléssel is elvégezték. Eredményük szerint a transzkraniális ingerlés hatására a vak személyek a látókkal ellentétben rosszul teljesítenek a verbális feladatban (fốneveket hallottak, amelyekre egy releváns igét kellett mondaniuk).

Absztrakt szófelidézésból álló verbális memóriafeladatoknál nagy fokú aktivitás mérhetố a vakon született személyek bal vizuális kortexében. A bal oldali aktivitás a V1 területrôl ered, és az extrastriatális retinotóp területeken keresztül a nonretinotóp területekbe - mint a laterális okcipitális komplex (LOC) - nyúlik be. További érdekesség, hogy a verbális memóriakapacitása, az elóhívás mértéke és a V1-aktivitás nagysága között erôs korreláció mutatható ki. A vak személyek hat hónap után több szóra emlékeztek, és nagyobb V1-aktivitást mutattak, mint a látó személyek. A V1-aktivitás és a teljesítmény között csak a vak személyek esetében lehetett korrelációt mérni (Amedi és mtsai, 2003). Egy következó vizsgálat során, amikor a bal calcarinus árkot vagy a bal okcipitális kortexet rTMS segítségével leválasztották, az igeképzés megoldási aránya nagymértékben romlott (Amedi, Floel, Knecht, Zohary és Cohen, 2004). Az utólagos analízis során kiderült, hogy a hibák szemantikai jellegúek voltak inkább, fonológiai és motoros hibák csak elvétve jelentek meg.

Így elmondható, hogy vak személyek esetében a bal okcipitális kéreg ideiglenes léziója a magasabb szintú verbális feldolgozási folyamatokkal, és nem csupán a taktilis vagy a Braille-olvasás ingereivel interferál. Vagyis a látókéreg olyan magasabb kognitív funkciókat is ellát, mint például a szemantikai feldolgozás. A korai életkorban kialakult vakság esetében a szenzoros rendszer változásai mögött valószínúleg a vizuálisan deafferentált okcipitális kéreg áll, mely így - új neurális kapcsolataival - magasabb kognitív funkciókban képes részt venni.

Bedny, Richardson és Saxe (2015) kutatócsoportja kimutatta, hogy a vak gyermekek vizuális kérgének hangokra (nem beszédhangokra) történô aktivitása 4 és 17 éves koruk között növekszik, továbbá, hogy a 4 éves vak gyermekek okcipitális kérge beszédhangokra is aktív. Az eredmény azt sejteti, hogy az okcipitális kéreg plaszticitása a beszédhangokra nézve független az egyéb hangok észlelésétôl és a Braille-tanuláshoz köthetố plaszticitástól. A vizuális input hiányakor az agykéreg fejlôdése során a beszédhangok mintegy „megszállják” a látórendszert. Korai életkorban a humán agykéreg rendkívül széles komputációs kapacitással bír. Ugyanaz a kéregterület vesz részt a vizuális percepcióban és a nyelvi folyamatokban is.

\section{A KÖRNYEZET SZEREPE A VAK GYERMEKEK NYELV- ÉS BESZÉDFEJLÔDÉSÉBEN}

Mint láthattuk, az agykérgi plaszticitás biztosítja, hogy vizuális depriváció következtében sem alakul ki funkcióvesztett kéregrész, hanem a nyelvi folyamatok kiépülésébe is bekapcsolódnak új területek. Mivel neurális szinten, súlyos fokú látássérülés esetén is biztosított a nyelv- és a beszédfejlôdés háttere, ezért a nyelv és a beszéd elsajátításakor a vizualitás hiányából adódó hátrányok kompenzálásában a környezet szerepe megnó. A legnagyobb nehézség a vak és a látó diádok közötti kommunikációs markerek kiépítésében, alkalmazásában és a kommunikáció fenntartásában figyelhetô meg. 
Vak gyermekeknél kevesebb spontán vokalizáció figyelhetô meg, ritkábban kezdeményeznek kommunikációt. Nehézség adódik a témaválasztásban, a téma fenntartásában, az összefüggô diszkurzusok kialakításában, továbbá a deiktikus markerek ${ }^{3}$ alkalmazásában (Barry, 2002). Egy korai vizsgálatban a deiktikus markerek használatával kapcsolatban Wales (1979) leírja, hogy vak gyermekek is használják az „itt”, „ott” terminusokat a lokalizációhoz, azonban nem szenzitívek a másik beszéló ezen markereinek figyelembevételére.

Mint már említettük, a vak gyermekek sokkal késôbb használnak funkciószavakat, beszédük több imperatív igealakot tartalmaz a látó gyermekekhez képest. Ennek egyik oka az lehet, hogy a vak gyermekeknél a közös figyelmi viselkedés hiánya miatt a szülô több felszólítást alkalmaz, amit a gyermek a beszédében tükröz (Pérez-Pereira és Conti-Ramsden, 1999).

A szülők gazdag outputot szeretnének, örülnek a gyermek „választékos beszédének”, azonban ezek a megnyilatkozások sokszor a tartalom szerint irrelevánsak (Dunlea, 1989). A szülő́k kevéssé figyelnek arra a tényre, hogy vak gyermekeknél a nyelv célja tágabban értelmezhetô. Nem csupán kommunikációra használják, hanem „magányos játékként" is.

Urwin (1983) vizsgálatai szerint a vak gyermek figyelmét nagymértékben elô lehet hívni és fejleszteni a gyermekmondókákkal, mivel azok mozgásokat (tapsolás, ringatás, „höcögtetés”) tartalmaznak a ritmusok és verbális akciók mellett. Ezek a közös rutinok képezhetik az alapját a szociális interakciók kezdeményezésének és kontrolljának a második életévben. Azonkívül, hogy a szókincs is fejlődik ezáltal, a látó gyermekekkel is interakciós lehetôséget biztosít. A verbális rutinok kihatása nagymértékben pervazív, ami kompenzálja a látás hiányából adódó nehezített kölcsönös kommunikációt. A szerzô leírja továbbá, hogy a vak kisgyermekeknél a 18 hónapos kor körül megfigyelhetô gyors szókincsnövekedéssel egyidejúleg jelentkeznek a reprezentációk. A reprezentációk kialakulása a látó kisgyermekekkel ellentétben nem a tárgyakkal való játékhoz kötött, hanem a kölcsönös dialógusokhoz, verbális interakciókhoz. A vak kisgyermek az elsố életévben megtanulja, hogy egy személyhez több hangszínt is lehet kapcsolni stb. Ebben a legkiemelkedóbb pont, hogy a vak kisgyermek a nyelvet kezdi el lehetséges reprezentációként használni. Ez ellentmond Fraiberg (1977) megállapításának, mely szerint a vak gyermekek szelf-reprezentációja és helyes névmáshasználata jóval késôbb fejlôdik ki, és a tárgyakkal való játékhoz köthetô. Andersen, Dunlea és Kekelis (1984) szerint azonban a vak gyermekeknek nehézségük van a perspektívaváltás megértésével, a többjelentésú szavak használatával és különösen a deiktikus terminusokkal. Megfigyelhetố továbbá, hogy a verbális szerepjátékok során mások által kevésbé hagyják magukat irányítani, és a látó gyermekekhez viszonyítva sokkal inkább az elsôdleges gondozójuk nyelvét (ideértve intonáció, hanghordozás, szófordulatok stb.) használják. ${ }^{4}$ A vak gyermek számára a nyelv válik elkerülhetetlenül is a kapcsolat felvételének és fenntartásának eszközévé. A tárgyakkal való aktivitás helyett a beszéd az

3 Deiktikus marker: olyan lexikai vagy grammatikai jelölô, amely a megnyilatkozást a beszédhelyzethez köti. Többnyire a helyet, az idôt vagy a személyt jelöli.

Ezt a karakterisztikus viselkedést a '70-80-as évek több irodalma „késleltetett echoláliának” (delayed echolalia) írja le. 
irányító, ami ahhoz vezet, hogy a gyermek elsôsorban magára fókuszál bármilyen más ágens helyett, kevéssé monitoroz a szelfjén kívül (Kekelis és Andersen, 1984).

Nehézségekbe ütközik/ütközhet vak gyermekkel való interakciókor, hogy egyik fél sem képes kellően monitorozni a másik perspektíváját és tapasztalatait. Az anyák gyermekük vakságának kompenzálásaként - többször érintik meg óket, és nem csupán a gyermek vokalizálására válaszolnak vokalizálással, de annak mosolyára és egyéb viselkedésére is.

Fontos, hogy az anyák a lehető legkorábbi idôponttól részt vegyenek a gyermek vokalizációjában, hogy megértse, a szülői hangadás a szülőhöz tartozik. A szülôk érzelmeit számukra csak a hangok, szavak, mondatok paralingvisztikus jelei hordozzák a kisebb mennyiségú taktilis információ mellett. Azonban a szülói szerep megélését nehezíti, hogy a vak csecsemôk és kisgyermekek a látás hiánya miatt nem, vagy kevéssé keresik a szülóvel való interakciót (Ingsholt, 2006).

\section{KÖVETKEZTETÉSEK}

A vakon született gyermekek nyelv- és beszédfejlődésében apróbb eltérések tapasztalhatók a látó társaik fejlôdésével összehasonlítva. Ezek az apróbb különbségek azonban átlagosan 5-10 éves korukra rendezôdnek.

Súlyos fokban látássérült gyermekek körében végzett vizsgálatokból kiderül, hogy a verbális memóriafeladatban a vak csoport fölénye nem egyértelmú, azonban a kategóriák elôhívása azonos módon és mértékben történik a látó személyekhez viszonyítva. A fonémaalapú elôhívás mint szótalálási stratégia jobb eredményhez vezet a csoport esetében. A szavak keresése tehát számukra könnyebb fonémahangzás, mint kategória szerint. A vak (felnôtt) személyeknél jobb auditív és emlékezeti funkciók, továbbá jobb beszéddiszkrimináció figyelhetô meg. Azonban fontos megjegyeznünk, hogy a látó kontrollcsoportok eredményeihez viszonyított pozitív irányú eltérés egyik lehetséges oka a vak személyek nagyobb auditív szenzoros szenzitivitása. A vizuális inger hiányában sem alakulnak ki az agykéreg különböző területein inaktív területek, mivel az agyi plaszticitás eredményeképpen például a vizuális kéreg is részt vesz többek között az auditív nyelvi feladatokban, és a beszédfeldolgozásban is. Auditív nyelvi feladatok esetén a vakon született személyek okcipitális-kérgi aktivitása nagyobb. A bal oldali okcipitális területek hozzájárulhatnak a nyelvi feldolgozáshoz, a nyelvi információk kódolásához és fenntartásához, a mondatstruktúra felépítéséhez és/vagy a szó jelentésének hosszú távú emlékezetból való előhívásához. Mint láthattuk, a humán agykéreg adott területe a fejlôdés korai szakaszában többféle funkció ellátására képes módosulni. Vagyis a nyelvelsajátítás idegrendszeri bázisa adott a vakon született gyermekek esetén is. Így a környezet szerepe megnố a vak gyermekek nyelv- és beszédelsajátítása során. A környezetnek figyelembe kell vennie a megfelelô kommunikáció elsajátítását és elsajátíttatását, a fogalmak kialakulásának fontosságát, illetve a látássérült gyermek nyelvhez és beszédhez való speciális viszonyát. 


\section{IRODALOM}

Amedi, A., Floel, A., Knecht, S., Zohary, E., \& Cohen, L. G. (2004). Transcranial magnetic stimulation of the occipital pole interferes with verbal processing in blind subject. Nature Neuroscience, 7(11), 1266-1270.

Amedi, A., Jacobson, G., Hendler, T., Malach, R., \& Zohary, E. (2002). Convergence of Visual and Tactile Shape Processing in the Human Lateral Occipital Complex. Cerebral Cortex, 12(11), 1202-1212.

Amedi, A., Raz, N., Pianka, P., Malach, R., \& Zohary, E. (2003). Early 'visual' cortex activation correlates with superior verbal memory performance in the blind. Nature Neuroscience, 6(7), $758-766$.

Andersen, E., Dunlea, A., \& Kekelis, L. (1984). Blind children's language: Resolving some differences. Journal of Child Language, 11(3), 645-664.

Ashmead, D. H., Wall, R. S., Ebinger, K. A., Eaton, S. B., Snook-Hill, M. M., \& Yang, X. (1998). Spatial hearing in children with visual disabilities. Perception, 27(1), 105-122.

Barry, A. K. (2002). Linguistic perspectives on language and education. Westport: Greenwood Publishing Group.

Bedny, M., Richardson, H., \& Saxe, R. (2015). 'Visual' Cortex Responds to Spoken Language in Blind Children. Journal of Neuroscience, 35(33), 11674-11681.

Bigelow, A. E. (1986). The development of reaching in blind children. British Journal of Developmental Psychology, 4(4), 355-366.

Bigelow, A. E. (2005). Blindness and psychological development of young children. In B. Hopkins (Ed.), Cambridge Encyclopedia of Child Development. Cambridge, UK: Cambridge University Press.

Bliss, I., Kujala, T., \& Hamalainen, H. (2004). Comparison of blind and sighted participants' performance in a letter recognition working memory task. Brain Research: Cognitive Research, 18(3), 273-277.

Brambring, M. (2006). Early intervention with infants and preschoolers who are blind. Bielefeld Observation Scales. Würzburg, Germany: Edition Bentheim.

Brambring, M. (2007). Divergent Development of Verbal Skills in Children Who Are Blind or Sighted. Journal of Visual Impairment and Blindness, 101(12), 749-762.

Burton, H., Snyder, A. Z., Diamond, J. B., \& Raichle, M. E. (2002). Adaptive changes in early and late blind: a FMRI study of verb generation to heard nouns. Journal of Neurophysiology, 88(6), 3359-3371.

Collignon, O., Lassonde, M., Lepore, F., Bastien, D., \& Veraart, C. (2007). Functional cerebral reorganization for auditory spatial processing and auditory substitution of vision in early blind subjects. Cerebral Cortex, 17(2), 457-465.

Corballis, M. C. (2002). From hand to mouth. Princeton: Princeton University Press.

Csákvári J. (2009) . A közös figyelmi helyzet (joint attention) jelenségének különbözô megközelítései, jellegzetességei látássérülés és autizmus spektrum zavar esetén. Gyógypedagógiai Szemle, $37(1), 2-10$.

Csépe V. (2005). Kognitív fejlódés-neuropszichológia. Budapest: Gondolat Kiadó.

Dabrowska, E. (2004). Language, mind and brain: some psychological and neurological constraints on theories of grammar. Edinburgh: Edinburgh University Press.

Dekker, R. (1993). Visually impaired children and haptic intelligence test scores: Intelligence Test for Visually Impaired Children (ITVIC). Developmental Medicine E Child Neurology, 35(6), 478-489.

Dunlea, A. (1989). Vision and the emergence of meaning. Blind and sighted children's early language. Cambridge, UK: Cambridge University Press. 
Dunlea, A. \& Andersen, E. (1992). The emergence process: conceptual and linguistic influences on morphological development. First Language, 12(34), 95-115.

Egyed K., Király I., Krekó K., Kupán K., \& Gergely G. (2007). Understanding object-referential attitude expressions in 18-month-olds: The interpretation switching function of ostensive-communicative cues. Poster presented at the Biennial Meeting of the SRCD, Boston, August, 2007.

Elbert T., Sterr A., Rockstroh B., Pantev C., Müller M. M., \& Taub E. (2002). Expansion of the tonotopic area in the auditory cortex of the blind. Journal of Neuroscience, 22(22), 9941-9944.

Fraiberg, S. (1977). Insight from the Blind. New York: Souvenir Press Ltd.

Garai Sz. (2004). Vak gyermekek beszédének pragmatikai szempontú vizsgálata. Szakdolgozat. Budapest: ELTE BGGYFK.

Gougoux, F., Lepore, F., Lassonde, M., Voss, P., Zatorre, R. J., \& Belin, P. (2004). Pitch Discrimination in the Early Blind. Nature, 430(6997), 309.

Gyốri M. (2013). Az irónia megértése autizmusban: egy kognitív pragmatikai modellhelyzet. Általános Nyelvészeti Tanulmányok, 25, 285-312.

Hauser, M. D., Chomsky, N., \& Fitch, W. D. (2002). The faculty of language: What is it, who has it, and how did it evolve? Science, 298(5598), 1569-1579.

Hoff, E. (2005). Language development. Thomson Learning, USA: Wadsworth Publishing.

Hötting, K., Rösler, F., \& Röder, B. (2004). Altered auditory-tactile interactions in congenitally blind humans: an event-related potential study. Experimental Brain Research, 159(3), 370-381.

Hötting, K., \& Röder, B. (2009). Auditory and auditory-tactile processing in congenitally blind humans. Hearing Research, 258(1-2), 165-174.

Hugdahl, K., Ek, M., Takio, F., Rintee, T., Tuomainen, J., Haarala, C., \& Hämäläinen, H. (2004). Blind Individuals Show Enhanced Perceptual and Attentional Sensitivity for Identification of Speech Sounds. Cognitive Brain Research 19(1), 28-32.

Hull, T., \& Mason, H. (1995). Performance of blind children on digit span tests. Journal of Visual Impairment E Blindness, 89(2), 166-169.

Ingsholt, A. (2006). Joint Attention and Social Development. Mary Kitzinger Trust Conference, London: Kington University.

Johnston, J. C., \& Schembri, A. (2013). Corpus analysis of sign languages. In C. A. Chapelle (Eds), The encyclopedia of applied linguistics (pp. 479-501). Malden MA \& Oxford: Wiley-Blackwell.

Kekelis, L., \& Andersen, E. (1984). Family communication styles and language development. Journal of Visual Impairment $\mathcal{E}$ Blindness, 78(2), 54-65.

Kocsis K. (1999). Verbalizmus vak gyermekeknél. A vak gyermekek legfontosabb nyelvi fejlódésbeli eltérései a látóktól különös tekintettel a verbalizmus jelenségére. Szakdolgozat. Budapest: ELTE BGGYTF.

Kujala, T., Alho, K., Huotilainen, M., Ilmoniemi, R. J., Lehtokoski, A., Leinonen, A., Rinne, T., Salonen, O., Sinkkonen, J., Standertskjold-Nordenstam, C. G., \& Naatanen, R. (1997). Electrophysiological evidence for cross-modal plasticity in humans with early and late-onset blindness. Psychophysiology, 34(2), 213-216.

Landau, B., \& Gleitman, L. R. (1985). Language and experience: Evidence from the blind child. Cambridge, MA: Harvard University Press.

Lukács, Á., Kas, B., \& Leonard, L. B. (2013). Case marking in Hungarian children with specific language impairment. First Language, 33(4), 331-353.

Mészáros V. (2004). Vak gyermekek beszédének mondattani elemzése. Szakdolgozat. Budapest: ELTE BGGYFK.

Marton K. (2009). Specifikus nyelvi zavar jellemzi-e a specifikus nyelvi zavart mutató gyermekeket? In Marton K. (szerk.), Neurokognitív fejlôdési zavarok vizsgálata és terápiája: példák a bi- 
zonyitékon alapuló gyakorlatra (pp. 61-101). Budapest: ELTE Eötvös Kiadó, ELTE Bárczi Gusztáv Gyógypedagógiai Kar.

Mildner G. (2003). Beszédhibák aránya gyengénlátók speciális iskoláiban tanuló gyermekek körében. Szakdolgozat. Budapest: ELTE BGGYFK.

Mills, A. E. (1987). The development of phonology in the blind child. In B. Dodd, \& R. Campell (Eds), Hearing by eye: The psychology of lip-reading (pp. 145-162). Hove. UK: Lawrence Erlbaum Associates.

Németh D. (2006). A nyelvi folyamatok és az emlékezeti rendszerek kapcsolata. Budapest: Akadémiai Kiadó.

Pajor E., Beke A. M., \& Csépe V. (2016). A 7 és 15 éves vak gyermekek emlékezeti, nyelvi és téri feldolgozás mutatói. Magyar Pszichológiai Szemle, 71(3-4), 471-495.

Pál Zs. (2012). Látássérült gyermekek spontán beszédvizsgálata DSS technika segítségével. Szakdolgozat. Budapest: ELTE BGGYK.

Pérez-Pereira, M., \& Conti-Ramsden, G. (1999). Language development and social interaction in blind children. Hove, UK: Psychology Press.

Peters, A. (1974). The beginnings of speech. Stanford Papers and Reports in Child Language Development, 8, 26-32.

Pléh Cs. (2009). A nyelv keletkezése. In Kovács I., \& Szamarasz V. Z. (szerk.), Látás, nyelv, emlékezet (pp. 59-75). Budapest: Typotex.

Pléh Cs., \& Lukács A. (szerk.) (2001). A magyar morfológia pszicholingvisztikája. Budapest: Osiris Kiadó.

Price, C. J. (1998). The functional anatomy of word comprehension and production. Trends in Cognitive Sciences, 2(8), 281-288.

Pring, L. (1992). More than meets the eye. In R. Campbell (Ed.), Mental lives: Case studies in cognition. Oxford, UK: Basil Blackwell.

Prónay B. (2004). Vak gyermekek verbális intelligenciájának vizsgálata. Tapasztalatok a MAWGYI-R teszttel. Magyar Pszichológiai Szemle, 59(1), 57-75.

Radványi K., \& Pléh Cs. (2002). Középsúlyos értelmi fogyatékos, iskoláskorú gyermekek beszédének néhány nyelvtani jellemzóje. Pszichológia, 22(3), 245-253.

Rokem, A., \& Ahissar, M. (2009). Interactions of cognitive and auditory abilities in congenitally blind individuals. Neuropsychologia, 47(3), 843-848.

Röder, B., \& Neville, H. J. (2003). Developmental functional plasticity. In J. Grafman, \& I. H. Robertson (Eds), Plasticity and Rehabilitation (pp. 231-270). Amsterdam: Elsevier Science B. V.

Röder, B., \& Rösler, F. (2003). Memory for environmental sounds in sighted, congenitally blind and late blind adults: Evidence for cross-modal compensation. International Journal of Psychophysiology, 50(1-2), 27-39.

Röder, B., Rösler, F., \& Neville, H. J. (2001). Auditory memory in congenitally blind adults: A behavioral-electrophysiological investigation. Brain research. Cognitive brain research, 11(2), 289-303.

Röder, B., Stock, O., Neville, H. J., Bien, S., \& Rösler, F. (2002). Brain activation modulated by the comprehension of normal and pseudo-word sentences of different processing demands: A functional magnetic resonance imaging study. NeuroImage, 15(4), 1003-1014.

Sáfár A. (2014). A jelnyelvek pszicholingvisztikája. In Pléh Cs., \& Lukács Á. (szerk.), Pszicholingvisztika 2. (pp. 1245-1264). Budapest: Akadémia Kiadó.

Stevens, A. A., \& Weaver, K. E. (2009). Functional characteristics of auditory cortex in the blind. Behavioural Brain Research, 196(1), 134-138.

Szabó M. H. (2007). A magyar jelnyelv szublexikális szintjének leírása. Budapest: Akadémiai Kiadó. 
Szúcs Jánosné (2008). Értelmileg súlyos fokban akadályozott látássérült gyermekek kommunikációfejlesztésének egy lehetséges módja. Szakdolgozat. Budapest: ELTE BGGYFK.

Urwin, C. (1978). The Development of Communication between Blind Infants and their Parents. In A. Lock (Ed.), Action, Gesture and Symbol (pp. 78-108). London, UK: Academic Press.

Urwin, C. (1983). Dialogue and cognitive functioning in the early language development of three blind children. In A. E. Mills (Ed.), Language acquisition in the blind child: Normal and deficient (pp. 142-161). London: Croom Helm.

Wakefield, C. E., Homewood, J., \& Taylor, A. J. (2006). Early blindness may be associated with changes in performance on verbal fluency tasks. Journal of Visual Impairment and Blindness, 100(5), 306-310.

Wales, R. (1979). "Deixis." In P. Fletcher, \& M. Garmen (Eds), Language acquisition: studies in first language development (pp. 119-127). Cambridge, UK: Cambridge University Press.

Wanet-Defalque, M. C., Veraart, C., De Volder, A., Metz, R., Michel, C., Dooms, G., \& Goffinet, A. (1988). High metabolic activity in the visual cortex of early blind human subjects. Brain Research, 446(2), 369-373.

\title{
SPECIAL CHARACTERISTICS AND BACKGROUND OF SPEECH AND LANGUAGE DEVELOPMENT IN BLIND CHILDREN
}

\section{PAJOR, EMESE - BEKE, ANNA MÁRIA - CSÉPE, VALÉRIA}

\begin{abstract}
Aim: The goal of our review is to present an unresearched field, namely speech and language development in blind children.

Method: There are only a few related publications, mostly case studies. The reason is the small number of the population and different development in blind children. In this paper publications which were written in this topic are reviewed.

Conclusion: Differences in speech and language development of blind children are meaningful in formation of categories and representations or rather in communication which decreases by school age. In comparison to sighted children, the blind group performs better verbal working memory capacity and phonemic fluency, which may be caused by better coding of auditory information and phoneme-based word recognition strategies. A better verbal working memory and auditory perceptive benefit are typical in adulthood, too. The neural background is ensured because there are no inactive cortical regions after visual deprivation. The role of the environment in blind children's speech and language development therefore is crucial.
\end{abstract}

Keywords: blindness, speech and language development, neural plasticity

A cikk a Creative Commons Attribution 4.0 International License (https://creativecommons. org/licenses/by/4.0) feltételei szerint publikált Open Access közlemény, melynek szellemében a cikk bármilyen médiumban szabadon felhasználható, megosztható és újraközölhetô, feltéve, hogy az eredeti szerzó és a közlés helye, illetve a CC License linkje és az esetlegesen végrehajtott módosítások feltüntetésre kerülnek. (SID_1) 